\title{
Electrospray-Induced Mass Spectrometry Is Not Suitable for Determination of Peptidic Cu(II) Complexes
}

\author{
Dawid Płonka, Radosław Kotuniak, Katarzyna Dąbrowska, and Wojciech Bal* \\ Cite This: J. Am. Soc. Mass Spectrom. 2021, 32, 2766-2776 \\ Read Online
}

ABSTRACT: The toolset of mass spectrometry (MS) is still expanding, and the number of metal ion complexes researched this way is growing. The $\mathrm{Cu}$ (II) ion forms particularly strong peptide complexes of biological interest which are frequent objects of MS studies, but quantitative aspects of some reported results are at odds with those of experiments performed in solution. $\mathrm{Cu}$ (II) complexes are usually characterized by fast ligand exchange rates, despite their high affinity, and we speculated that such kinetic lability could be responsible for the observed discrepancies. In order to resolve this issue, we selected peptides belonging to the ATCUN family characterized with high and thoroughly determined $\mathrm{Cu}$ (II) binding constants and re-estimated them using two ESI-MS techniques: standard conditions in combination with serial dilution experiments and very mild conditions for competition experiments. The sample acidification, which accompanies the electrospray formation, was simulated with the $\mathrm{pH}-$ jump

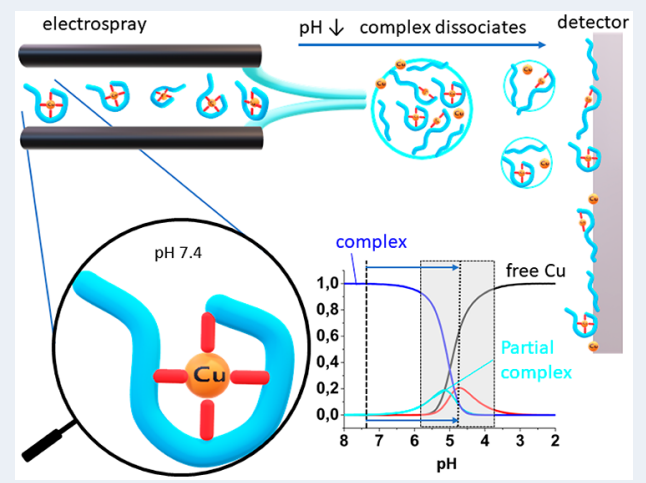
stopped-flow technique. Our results indicate that ESI-MS should not be used for quantitative studies of $\mathrm{Cu}(\mathrm{II})$-peptide complexes because the electrospray formation process compromises the entropic contribution to the complex stability, yielding underestimations of complex stability constants.

\section{INTRODUCTION}

Complexation to peptides is proposed to play important roles in $\mathrm{Cu}$ (II) physiology and toxicology. $\mathrm{Cu}$ (II) activates $\mathrm{GHK}$, a wound healing factor ${ }^{1,2}$ and $\alpha$-factor, a yeast pheromone, ${ }^{3,4}$ and is likely transported to neurons by neurokinin $\mathrm{B} .^{5}$ It also elicits toxicity and probably gets detoxified by some variants of $\mathrm{A} \beta$ peptides ${ }^{6,7}$ and protamine $\mathrm{HP} 2^{8-10}$ and likely participates in the antifungal action of histatins, salivary antimicrobial peptides. ${ }^{11} \mathrm{~A}$ recent study indicated that more peptides with such properties remain to be identified in human proteome. ${ }^{12}$ Peptides have also been used extensively to model $\mathrm{Cu}$ (II) binding to its transport proteins, such as albumin and hCtrl membrane transporter, $^{13-15}$ and synaptic proteins, such as prions, APP, and $\alpha$ synuclein. ${ }^{16,17}$ Two N-terminal sequence motifs, Xaa-His and Xaa-Zaa-His (where Xaa is any $\alpha$-amino acid except of Cys, and Zaa is any $\alpha$-amino acid except of Cys or Pro), provide the highest $\mathrm{Cu}$ (II) complex affinities by virtue of synergistic formation of chelate rings involving peptide nitrogen atoms (Figure 1). ${ }^{18-20}$ The logarithmic conditional stability constants at physiological $\mathrm{pH} 7.4, \log { }^{\mathrm{C}} K_{7.4}$, for Xaa-His complexes are in the range of 12.5-13, while those of Xaa-Zaa-His complexes range from 12.3 to ca. $15 . .^{21,22}$ The latter are also known as ATCUN or NTS complexes. ${ }^{18}$

Mass spectrometry (MS) in its many variants is one of the most versatile techniques of peptide and protein research, providing information on their composition, sequence, and post-translational modifications and via hyphenated techniques also on protein structure. It has also been widely used to determine affinity constants of molecular complexes, using a number of experimental approaches, ${ }^{23-27}$ including studies of metal complexes. ${ }^{28}$ A significant work was devoted to developing best conditions for quantitative determinations, including optimization of spray formation. ${ }^{29,30}$

Under certain conditions, MS can also be used to obtain quantitative information on metal ion complexes, e.g., $\mathrm{Zn}$ (II), $\mathrm{Cu}(\mathrm{I})$ or $\mathrm{As}(\mathrm{III}) .^{31-34}$ It has also been used to determine the binding constants for $\mathrm{Cu}$ (II) complexes. ${ }^{34-36}$

One issue to consider is the rate at which the charged molecular ions are generated with respect to parallel changes in their environment. During the electrospray formation the time from injection of the sample from the capillary to the droplet fission takes a few milliseconds. ${ }^{37-39}$ Many metal ion complexes remain intact in this time scale due to their sufficient inertness in ligand exchange reactions. ${ }^{40}$ However, as recently demonstrated by stopped-flow and freeze-quench techniques, the formation of $\mathrm{Cu}(\mathrm{II})$ complexes with ATCUN peptides Gly-Gly-His and $\mathrm{A} \beta_{4-16}$ proceeds via a reactive intermediate step whose lifetime is in the hundred milliseconds range. ${ }^{20,41}$ The $\mathrm{Cu}$ (II) ion in this

Received: July 9, 2021

Revised: October 22, 2021

Accepted: October 25, 2021

Published: November 5, 2021

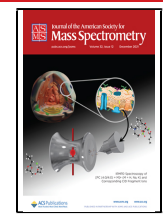




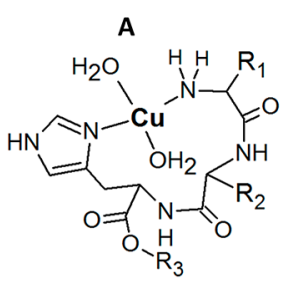

$2 N$ complex

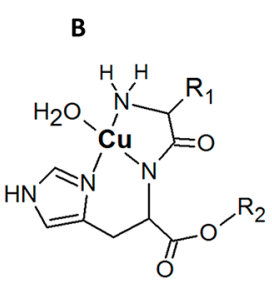

$3 N$ complex

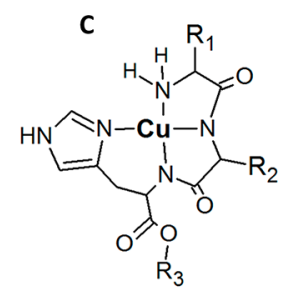

$4 N$ complex

Figure 1. Structures of $\mathrm{Cu}(\mathrm{II})$ complexes at the $\mathrm{N}$-terminal site of peptides having His in the $2^{\text {nd }}(\mathrm{B})$ or $3^{\text {rd }}$ position $(A)$ and $(C)$. $\mathrm{R}_{(\mathrm{n})}$ mark side chains and the remainder of the peptide chain.

Table 1. Comparison of Conditional $\mathrm{Cu}$ (II) Binding Constants of the Studied Peptides at $\mathrm{pH}=7.4\left({ }^{\mathrm{C}} \mathrm{K}_{7.4}\right)$, Compared to These Constants Determined Previously by Other Methods and Published ${ }^{a}$

\begin{tabular}{|c|c|c|c|c|}
\hline peptide sequence (name) & published log & $\begin{array}{c}\log K_{\mathrm{d}} \pm \text { SD from serial dilution ESI-MS } \\
\text { experiment in this study }\end{array}$ & $\begin{array}{c}\log \text { ratio } \log K_{\mathrm{d}} \text { (ESI-MS) - log } \\
{ }^{C} K_{7.4} \text { (published) }\end{array}$ & $\begin{array}{l}\text { range of concentrations in this } \\
\text { study }(\mu \mathrm{M})\end{array}$ \\
\hline DTHFPI-NH ${ }_{2}($ hepc6) & $14.7^{c}$ & $7.6 \pm 0.7$ & -7.1 & $100-0.01$ \\
\hline MNH-NH & $14.5^{d}$ & $6.3 \pm 0.4$ & -8.2 & $100-2$ \\
\hline FRHDSG $(\mathrm{A} \beta 4-9)$ & $14.2^{e}$ & $6.9 \pm 0.9$ & -5.3 & $100-1$ \\
\hline $\begin{array}{l}\text { FRHDSGYEVHHQK-NH }{ }_{2} \\
(\mathrm{~A} / 4-16)\end{array}$ & $13.5^{f}$ & $7.0 \pm 0.2$ & -6.5 & $100-0.5$ \\
\hline $\mathrm{MDH}-\mathrm{NH}_{2}$ & $13.1^{d}$ & $7.1 \pm 0.6$ & -6.0 & $100-1$ \\
\hline GGH & $12.2^{g}$ & $6.0 \pm 0.5$ & -6.2 & $100-10$ \\
\hline
\end{tabular}

${ }^{a}$ Standard deviation of ESI-MS experimental values are given in parentheses. Logarithmic values are given for better clarity. The published log ${ }^{\mathrm{C}} K_{7.4}$ values were determined by potentiometry and corroborated by spectroscopic methods. ${ }^{b}$ The SD values were considerably less than 0.1 log unit in all cases. ${ }^{c}$ Reference $63 .{ }^{d}$ Reference $64 .{ }^{e}$ Reference $65 .{ }^{f}$ Reference $6 .{ }^{g}$ Reference 21.

species is partially coordinated to the amine and imidazole nitrogens only (Figure 1A) and is considered to be kinetically labile. Such lability may in turn affect the apparent binding constant determination by exposing partially folded/coordinated complexes to the gas phase. Moreover, alternative complex stoichiometries can occur. For example, Matsumoto et al. discovered $\mathrm{Cu}$ (II) complexes that emerged rapidly in the gas phase but were not present in solution. ${ }^{42}$

In addition, the presence of stable, e.g., "physiological", conditions in the gas phase is very debatable. Protein and peptide structures are maintained through covalent bonds, hydrogen bonds, and hydrophobic interactions with a strong contribution from the solvent entropy. ${ }^{43,44}$ The $\mathrm{pH}$ and ionic strength cannot be defined anymore for the molecule after its transition to gas phase. Protonation states are altered ${ }^{45}$ and hydrophobic interactions get lost altogether, along with the evaporation of solvating water molecules. ${ }^{46}$ In contrast, electrostatic interactions, hydrogen bonds and van der Waals interactions are enhanced in the gas phase, prompting the loss of native structure. ${ }^{46}$ The MS measurement time scale is generally considered as too short for the protein or peptide unfolding, because it requires a concerted breaking of multiple noncovalent bonds. ${ }^{47,48}$ Some proteins may actually unfold in less than $1 \mathrm{~ms}$, however. ${ }^{49}$ Metal binding to a peptide contributes only a few coordination bonds, typically two to six, and perhaps several weaker interactions in the second coordination sphere. The loss of even one of them due to gas phase conditions will have a profound effect on the complex stability. This is particularly important for peptidic $\mathrm{Cu}$ (II) complexes in which the entropic contribution to stability is very significant. ${ }^{50,51}$

Next, the equilibrium could be shifted because the $\mathrm{pH}$ of electrospray droplets might be different from that set in the sample prior to the analysis. Finding an appropriate buffer for ESI-MS studies is a difficult task. ${ }^{52}$ Most buffers that maintain physiological $\mathrm{pH}$ do not qualify because their ionic character suppresses the signal. Ammonium acetate is commonly used as a "buffer" for so-called native ESI-MS experiments due to volatility of neutral forms of its components, acetic acid and ammonia, which form upon the spray evaporation and do not contribute to ionic noise. However, as pointed out by Konermann, ammonium acetate is not really a buffer at $\mathrm{pH} 7 .^{52}$ It has two buffering areas around the $\mathrm{pK}$ values of its components, at 4.75 \pm 1 for acetate and $9.25 \pm 1$ for ammonia. Hence, the rising number of $\mathrm{H}^{+}$ions produced by electric field in shrinking solvent droplets in the positive ion measurement mode rapidly decreases the droplet $\mathrm{pH}$, down to the acetate buffering range of $4.75 \pm 1$. Under these circumstances there is no straightforward way of determining how exactly the $\mathrm{pH}$ has changed during the measurement. This poses a serious problem for quantitative analysis because the binding constants may change drastically with $\mathrm{pH}$ (see Table 1 ). The situation is further aggravated when mixtures of water and organic solvents are used, making the $\mathrm{pH}$ even more difficult to ascertain. ${ }^{53}$ The discrepant effects of droplet acidification and other effects mentioned above on the characterization of metal ion complexes have been noted, e.g., for relatively weak complexes of alkaline earth metal ions with EDTA, ${ }^{54}$ or lanthanide complexes with acetate, ${ }^{55}$ but also for very tightly bound species, e.g., the $\mathrm{Bi}^{3+}$ complex of transferrin. ${ }^{56}$

Other available buffers offer little alternative. Ammonium bicarbonate has $\mathrm{p} K_{\mathrm{a}}=6.4$ but is unstable and prone to $\mathrm{CO}_{2}$ evolution, while common biologically friendly buffers, like Tris or HEPES, contain nonvolatile cations and anions, resulting in a poor MS data quality.

Furthermore, redox-prone metal complexes, including the $\mathrm{Cu}(\mathrm{II})$ species, may undergo reduction in the gas phase. This effect is independent of the method of ionization, as such behavior was reported in both electrospray and plasma desorption studies. ${ }^{57,58}$ It is difficult to monitor and can influence quantitative studies, as the copper oxidation state is 


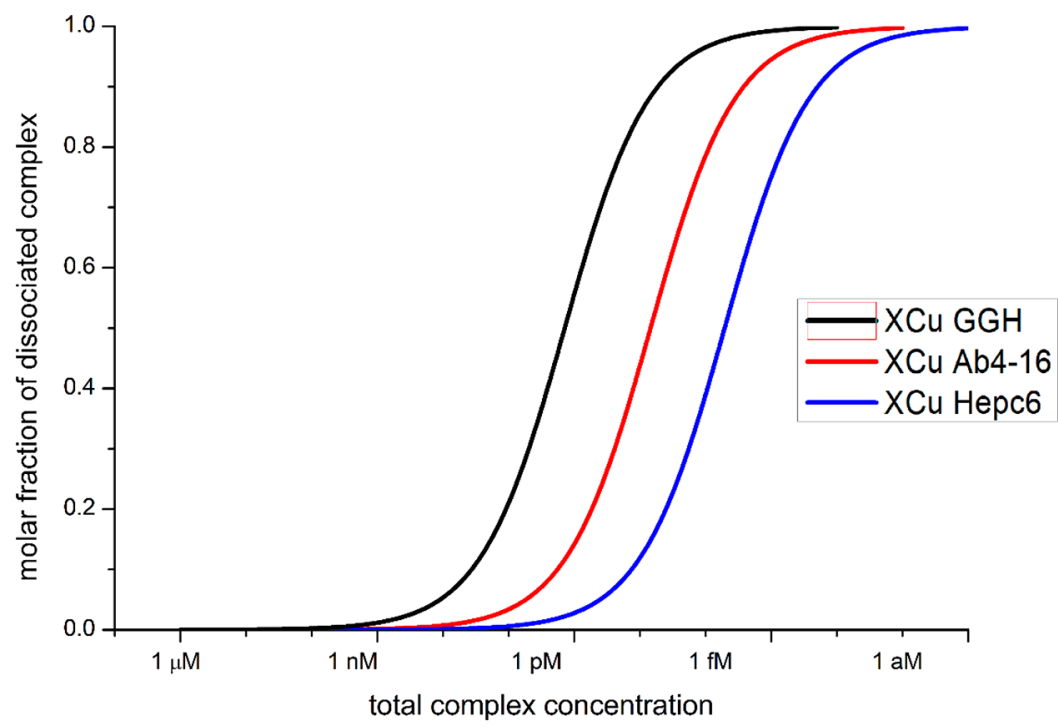

Figure 2. Theoretical dissociation curves of $\mathrm{Cu}(\mathrm{II}) /$ peptide 1:1 complexes at $\mathrm{pH}$ 7.4.

crucial for the complex formation and stability. For example, the ESI-MS experiments on the $\mathrm{Cu}(\mathrm{II})-\mathrm{GHK}$ peptide complex yielded a mixture of $\mathrm{Cu}(\mathrm{II})$ and $\mathrm{Cu}(\mathrm{I})$ species in a proportion depending on the electrostatic potential in the ion source. ${ }^{59}$ Tsybizova et al. listed three possible mechanisms for $\mathrm{Cu}$ (II) reduction: reduction on the capillary walls, desolvation with electron transfer and reduction while still in the solution. ${ }^{60}$ Reduction was more likely to occur when the $\mathrm{Cu}$ (II) ion was coordinated by no more than two atoms.

The unpredictability of issues with reduction and $\mathrm{pH}$ shift is aggravated by an uncertainty of the measurement time scale which depends on the droplet size. As a general rule, the bigger the droplet is, the longer time it takes to dissipate, extending the opportunity for unwanted processes to occur. ${ }^{61}$

In our laboratory practice, we frequently recorded ESI-MS spectra of $\mathrm{Cu}$ (II) complexes of peptides. Nearly always strong signals of unbound peptide were observed, although they were not present in equilibrium (see Figure 2 for examples). This strongly indicated that complex dissociation occurred in the mass spectrometer, yielding artifacts. On the other hand, ESIMS is often treated, e.g. by less experienced researchers as if it faithfully reflected the solution equilibria. The goal of our study was therefore to systematically explore the issue of a systematic error in attempts to study $\mathrm{Cu}(\mathrm{II}) /$ peptide complexes quantitatively by ESI-MS. In order to achieve it, we performed ESI-MS titration experiments on six high-affinity $\mathrm{Cu}(\mathrm{II})$ / peptide systems which we previously characterized in a comprehensive fashion.

We started with serial dilution experiments on a standard ESIMS instrument in order to obtain apparent affinity constants serving for quantitative illustration of the scale of the systematic error generated by ESI-MS. This was followed by $\mathrm{pH}-$ jump kinetic experiments aimed to model events occurring in the evaporating spray droplets and by additional competition-based affinity studies performed on an ESI-MS instrument dedicated for studies of noncovalent interactions. All these experiments yielded a clear and unequivocal view that ESI-MS should not be used for quantitation of $\mathrm{Cu}(\mathrm{II}) /$ peptide complexes.

\section{EXPERIMENTAL SECTION}

L-Histidine and ammonium acetate were purchased from Sigma. All peptides, except for GGH purchased from Sigma, were synthesized in-house with standard Fmoc solid phase synthesis, as described before. ${ }^{62}$ Crude synthesis products were purified with RP-HPLC on ACE C18-300 column $250 \times 8 \mathrm{~mm}$ with a rising gradient of acetonitrile in water with $0.1 \%$ TFA.

ESI-MS spectra were recorded on a Premier ESI-QToF spectrometer (Waters). All measurements were performed in the positive ion mode. The source temperature $80{ }^{\circ} \mathrm{C}$ was used for a complete desolvation of the peptide ions. The cone voltage was $10 \mathrm{~V}$ for shorter peptides and $30 \mathrm{~V}$ for $\mathrm{A} \beta_{4-16}$. The transmission of the ions was optimized on the quadrupole for the required mass range $(\mathrm{m} / z 200$ to 1000 for shorter peptides, $\mathrm{m} / z$ 300 to 1500 for $\mathrm{A} \beta_{4-16}$ ). Mass spectra were accumulated over 2 to $3 \mathrm{~min}$ to improve the signal-to-noise ratio. The sample flow was $20 \mu \mathrm{L} / \mathrm{min}$. The $100 \mu \mathrm{M} \mathrm{Cu}(\mathrm{II})$-peptide solutions in 20 $\mathrm{mM}$ ammonium acetate at $\mathrm{pH} 7.4$ were used for serial dilutions of the whole complex with the same ammonium acetate. For quantitation, all peaks corresponding to each charged state were integrated for each peptide. Ratios of free peptide to $\mathrm{Cu}$ (II)/ peptide complex were extracted from the integration of MS intensities with the assumption of similar ionization efficacy. For each dilution the $K_{\mathrm{d}}$ was calculated according to eq 1 , followed by the averaging as required (see the Results for details).

$$
K_{\mathrm{d}}=\frac{[\text { free peptide }]\left[\mathrm{Cu}^{2+}\right]}{[\mathrm{Cu} / \text { peptide }]}
$$

The free $\mathrm{Cu}^{2+}$ ions could not be detected directly, due to low $\mathrm{m} /$ $z$ and instead were calculated from the mass balance (free $\mathrm{Cu}^{2+}$ assumed to be equal to free peptide).

Isotopic distributions were calculated using built-in MassLynx Isotope model software (Waters).

Competition experiments with histidine were carried out on Q Exactive UHMR Hybrid Quadrupole-Orbitrap mass spectrometer (ThermoFisher Scientific). Samples were prepared by dissolving peptides in $50 \mathrm{mM}$ ammonium acetate $\mathrm{pH} 7.4$ in 100 $\mathrm{nM}$ concentration. To each sample a mixture of $100 \mathrm{nM} \mathrm{CuCl}_{2}$ and differing concentrations of histidine were added. Measurements started with an $1 \mathrm{~h}$ delay to allow for reaching equilibrium. Samples were introduced into the mass spectrometer with a 

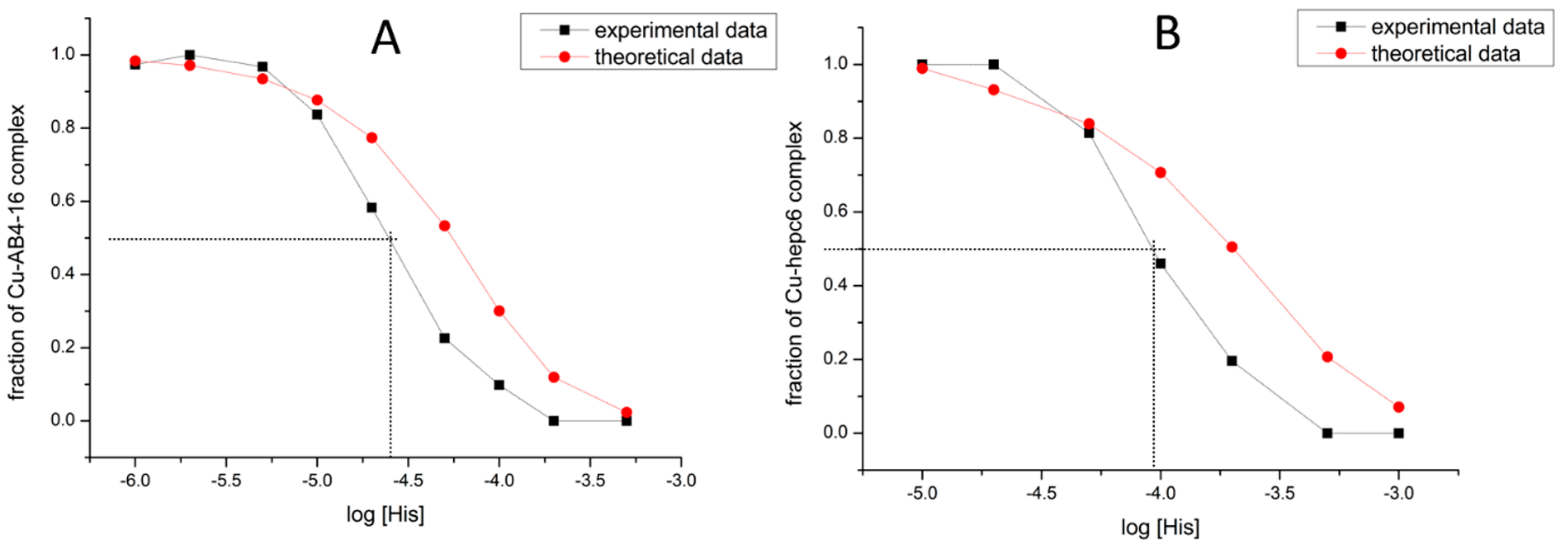

Figure 3. Experimental and theoretical binding isotherms for $\mathrm{Cu}(\mathrm{II}) / \mathrm{A} \beta 4-16$ (A) and $\mathrm{Cu}(\mathrm{II}) / \mathrm{hepc6}$ (B) $100 \mathrm{nM} 1: 1$ complexes titrated with histidine as a weak competitor. Dotted lines mark concentration at which $50 \%$ of the peptide is occupied with $\mathrm{Cu}(\mathrm{II})$ ion.

syringe pump using $10 \mu \mathrm{L} / \mathrm{min}$ flow rate, by electrospray ionization using positive mode in HESI source. MS measurements were conducted under the following settings: desolvation voltage: $20 \mathrm{~V}$, capillary temperature $320{ }^{\circ} \mathrm{C}$, detector $\mathrm{m} / z$ optimization: low $m / z$; ion transfer optimization to low $m / z$. The RF applied throughout the instrument were set to $150 \mathrm{Vp}-\mathrm{p}$ for injection flatapole, $300 \mathrm{Vp}$-p for bent flatapole, 250 for transfer multipole and HCD cell, and 2300 for C-trap. The ions transfer optics was to $5 \mathrm{~V}$ for injection flatapole, $4 \mathrm{~V}$ for intel flatapole, $2 \mathrm{~V}$ for bent flatapole and $0 \mathrm{~V}$ for transfer multipole. Integration of the resulting peaks was achieved with built-in software FreeStyle 1.4 (Thermo Scientific).

The stopped-flow SFM-300 (BioLogic) instrument was used to measure the rates of dissociation of $\mathrm{Cu}(\mathrm{II})-\mathrm{GGH}$ and $\mathrm{Cu}(\mathrm{II})-$ hepc 6 complexes upon acidification. The kinetic runs were observed with a diode-array detector (TIDAS S $500 \mathrm{~K}$, J\&M Analitik AG), with the spectra recorded in the 400-900 $\mathrm{nm}$ wavelength range at $1.5 \mathrm{~ms}$ intervals. Reactions were performed in a $1 \mathrm{~cm}$ path length cuvette at $25^{\circ} \mathrm{C}$. The dead time of the instrument was $2 \mathrm{~ms}$ at total flow rate $15 \mathrm{~mL} / \mathrm{min}$.

The $\mathrm{pH}$-jump experiments were carried out for solutions of 2 $\mathrm{mM}$ peptide and $1.8 \mathrm{mM} \mathrm{CuCl}_{2}$ in $50 \mathrm{mM}$ ammonium acetate at $\mathrm{pH}=7.4$ mixed with equal volumes of $45 \mathrm{mM}, 0.25 \mathrm{M}$, or $2.5 \mathrm{M}$ acetic acid, which resulted in sample acidification to $\mathrm{pH} 5,4$, or 3 , respectively. The dilution during the mixing yielded final cuvette concentrations of $1 \mathrm{mM}$ peptide, $0.9 \mathrm{mM} \mathrm{Cu}$ (II), and $22.5 \mathrm{mM}, 125 \mathrm{mM}$ and $1.25 \mathrm{M}$ acetic acid, respectively. The solutions were freshly prepared and degassed before each series of reactions. The final $\mathrm{pH}$ value was measured in the samples collected after each experiment. To show the differences in absorbance signal before the first recorded time point, the dilution of the $\mathrm{Cu}(\mathrm{II})$-peptide complex was measured as a control (shown as $t=0 \mathrm{~s}$ ). In all cases, the peptides were in a slight excess over $\mathrm{Cu}(\mathrm{II})$ to avoid $\mathrm{Cu}(\mathrm{OH})_{2}$ precipitation.

\section{RESULTS}

ESI-MS Attempts at Determining ${ }^{{ }^{C}} \mathrm{~K}$. To test the pseudophysiological ESI-MS conditions for the binding constant determination we employed two different mass spectrometers and two different techniques. Serial dilution studies of $\mathrm{Cu}$-peptide complexes were performed on a standard ESI-MS instrument, while histidine competition experiments were performed on a sensitive instrument dedicated for studies of noncovalent complexes.
In the first approach, we performed measurements on several synthetic peptides with well-established $\mathrm{Cu}$ (II) binding properties. Equimolar $\mathrm{Cu}(\mathrm{II})$ peptide mixtures $(100 \mu \mathrm{M})$ were dissolved in $20 \mathrm{mM}$ ammonium acetate at $\mathrm{pH}$ 7.4. The dissociation of complexes was monitored by serial dilutions of both reagents. Table 1 provides the $K_{\mathrm{d}}$ values obtained according to eq 1 for each data point and averaged. These values were compared to the literature ${ }^{\mathrm{C}} K_{7.4}$ values. ${ }^{6,21,63-65}$ Very large discrepancies were observed, ranging from five to eight log units.

The ESI-MS spectra are presented in Figures S1-S6. As seen in these figures, substantial amounts of unbound peptides were observed in all cases at all tested concentrations. For example, ca. $20 \%$ free peptide was detected throughout the dilution experiment for hepc6. This degree of $\mathrm{Cu}$ (hepc6) complex dissociation at $\mathrm{pH} 7.4$ should not occur above a complex concentration of $9 \mathrm{fM}$ (Figure 2). ${ }^{63}$ Further experiments were undertaken to explain the sources of this discrepancy.

For the peptides forming the weakest $(\mathrm{GGH})$ and the strongest complexes (hepc6), different $\mathrm{Cu}(\mathrm{II}) /$ peptide ratios were analyzed (Figure S7 and S8, respectively). The increasing $\mathrm{Cu}$ (II) amounts should eventually saturate the peptide, eliminating the apopeptide signals. This did not happen, even at the highest $\mathrm{Cu}$ (II) excess that could be achieved due to solubility, more than hundred-fold for GGH (Figure S7). As presented in Figure S9, increasing the $\mathrm{Cu}$ /peptide ratio lowered the apparent $K_{\mathrm{d}}$ value, contrary to what should be expected according to eq 1 .

We also analyzed the spectra for the signs of $\mathrm{Cu}(\mathrm{II})$ reduction to $\mathrm{Cu}(\mathrm{I})$ as a possible source of $K_{\mathrm{d}}$ value deviation. This effect would manifest itself qualitatively in the ESI-MS spectra as a $m / z$ shift of +1 for the molecular ions containing $\mathrm{Cu}(\mathrm{I})$, because the positive charge decrease on the copper ion would have to be compensated by an additional $\mathrm{H}^{+}$ion attached elsewhere. This, in turn, would affect the peak proportions in the ionic manifold. This effect was analyzed by comparing the peak maximum intensities with respect to the monoisotopic (highest) peak. Indeed, very slight increases of the second and fourth peaks were observed in most peptides, consistent with the +1 mass shift, but the effect was small, not exceeding a few percent of the monoisotopic peak (Figure $\mathrm{S} 10$ ). Thus, some $\mathrm{Cu}(\mathrm{II})$ reduction to $\mathrm{Cu}(\mathrm{I})$ could have occurred in our experiments, but its contribution to $K_{\mathrm{d}}$ was minimal to negligible.

Competition Experiments with Histidine. Having demonstrated that serial dilution experiments on a standard 
Table 2. Comparison of Conditional Cu(II) Binding Constants Obtained with Competition Experiments with Histidine of the Studied Peptides at $\mathrm{pH}=7.4\left({ }^{\mathrm{C}} K_{7.4}\right)$, Compared to These Constants Determined Previously by Other Methods and Published ${ }^{a}$

\begin{tabular}{|c|c|c|c|c|}
\hline peptide sequence (name) & $\begin{array}{l}\text { published } \\
\log { }^{C} K_{7.4}\end{array}$ & $\begin{array}{l}\log K_{\mathrm{d}} \text { from His competition ESI-MS } \\
\text { experiments in this study }\end{array}$ & $\begin{array}{c}\log \text { ratio } \log K_{\mathrm{d}} \text { (ESI-MS) - log } \\
{ }^{\mathrm{C}} K_{7.4} \text { (published) }\end{array}$ & $\begin{array}{l}\text { range of concentrations of histidine in } \\
\text { this study }(\mu \mathrm{M})\end{array}$ \\
\hline DTHFPI-NH ${ }_{2}$ (hepc6) & $14.66^{b}$ & 13.98 & -0.68 & $1000-10$ \\
\hline FRHDSGYEVHHQK-NH ${ }_{2}$ & $13.53^{c}$ & 12.84 & -0.69 & $500-1$ \\
\hline
\end{tabular}
(A $\beta 4-16)$

${ }^{a}$ Logarithmic values are given for better clarity. The published $\log { }^{C} K_{7.4}$ values were determined by potentiometry and corroborated by spectroscopic methods. ${ }^{b}$ Reference $63 .{ }^{c}$ Reference 6.
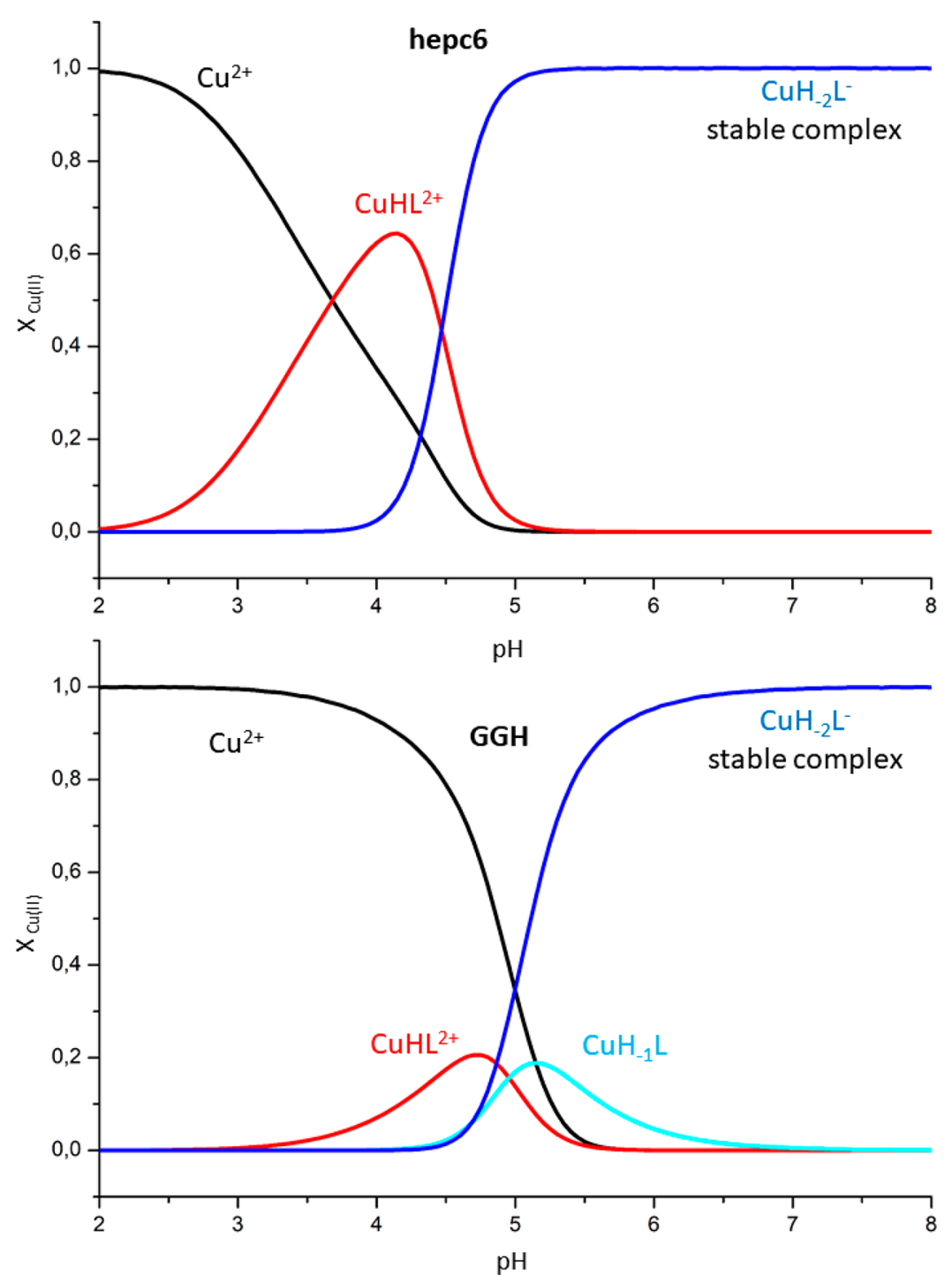

Figure 4. $\mathrm{pH}$-dependent species distribution of $\mathrm{Cu}$ (II) complexes of hepc6 (top) and GGH (bottom) calculated for $1 \mathrm{mM}$ peptides and $0.8 \mathrm{mM}$ $\mathrm{Cu}(\mathrm{II})$ based on potentiometric data from ref 65 and ref 21 , respectively.

ESI-MS instrument inadvertently yield artifacts, we checked whether competition experiments could provide a better result. For that we used a state-of-the-art Q-Exactive Ultra-High Mass Range mass spectrometer designed specially to preserve native noncovalent bonds. The initial experiment in $50 \mathrm{mM}$ ammonium acetate, $\mathrm{pH} 7.4$, proved that no artifactual complex dissociation occurred for the $\mathrm{CuA} \beta 4-16$ complex at the $100 \mathrm{pM}$ concentration, near the instrument's detection limit (Figure S11). According to Figure 2, this dilution was still 2 orders of magnitude away from the range at which serial dilution could be applied but gave promise for competition experiments. In this approach, $100 \mathrm{nM}$ peptides $\mathrm{A} \beta 4-16$ and hepc6 mixed with 100 $\mathrm{nM} \mathrm{Cu}(\mathrm{II})$ were titrated with histidine, which served as a weak competitor. With full knowledge of the protonation states and stability constants for each complex species in solution (Tables S1 and S2) we were able to calculate the theoretical binding isotherms indicating a feasibility of such approach. The experimental curves were unfortunately different (Figure 3 ).

Calculating binding constants from competition experiments where the competitor forms both 1:1 and 2:1 complexes is not an easy task in general, and competition may produce errors that are difficult to account for, ${ }^{66}$ but we were able to circumvent the 
calculation problem by extracting the histidine concentration at which $50 \%$ of peptides were bound to $\mathrm{Cu}$ (II) from Figure 3 . These values were $24.9 \mu \mathrm{M}$ His for $\mathrm{A} \beta 4-16$ and $93.3 \mu \mathrm{M}$ His for hepc6. With these values and the knowledge of all protonation constants of histidine and stability constants for $\mathrm{Cu}(\mathrm{II}) /$ histidine complexes ${ }^{67}$ we could calculate the binding constants using the competitivity index (CI) approach. ${ }^{68,69}$ The CI for a binary metal/ligand system is defined as the logarithm of the conditional stability constant of MZ (the metal complex of a theoretical molecule $\mathrm{Z})$, such that $\Sigma_{i j k}\left(\left[\mathrm{M}_{i} \mathrm{H}_{j} \mathrm{~L}_{k}\right]\right)=[\mathrm{MZ}]$, at given overall component concentrations, where $\mathrm{M}$ is a metal ion, $\mathrm{H}$ is hydrogen, and $\mathrm{L}$ is the metal binding ligand. In other words, the apparent stability constant of $\mathrm{MZ}$, in units of $\mathrm{M}^{-1}$, reflects the overall metal ion binding ability of all other molecules in equilibrium. $\mathrm{CI}$ is equivalent to $\log { }^{\mathrm{C}} K_{7.4}$ when there is only one complex species under given conditions but has a broader relevance if more than one species coexist in solution. In such case CI represents the metal binding properties of the whole ensemble of complex species. In the studied system $L$ is histidine and $\mathrm{Z}$ is the peptide. The data obtained through these calculations are gathered in Table 2, and raw spectra are shown in Figures S12 and S13.

Modeling the $\mathrm{pH}$ Drop in Electrospray Droplets Using $\mathrm{pH}$-jump Stopped Flow. The formation of $\mathrm{Cu}(\mathrm{II})$ - peptide complexes in general and ATCUN complexes in particular is very strongly $\mathrm{pH}$-dependent. ${ }^{18}$ This is illustrated in Figure 4 for hepc6 and GGH and in Figure S14 for other studied peptides. These diagrams indicate that the significant coexistence of $\mathrm{Cu}(\mathrm{II})$-bound and unbound peptides occurs typically in the $\mathrm{pH}$ range between 3 and 5 . The presence of unbound peptides in all serial dilution ESI-MS experiments could thus be a simple consequence of acidification of sample droplets containing ammonium acetate during their evolution in electrospray. ${ }^{52}$

Figure 5 provides the correlation diagram indicating what $\mathrm{pH}$ values in electrospray droplets would explain the apparent loss of

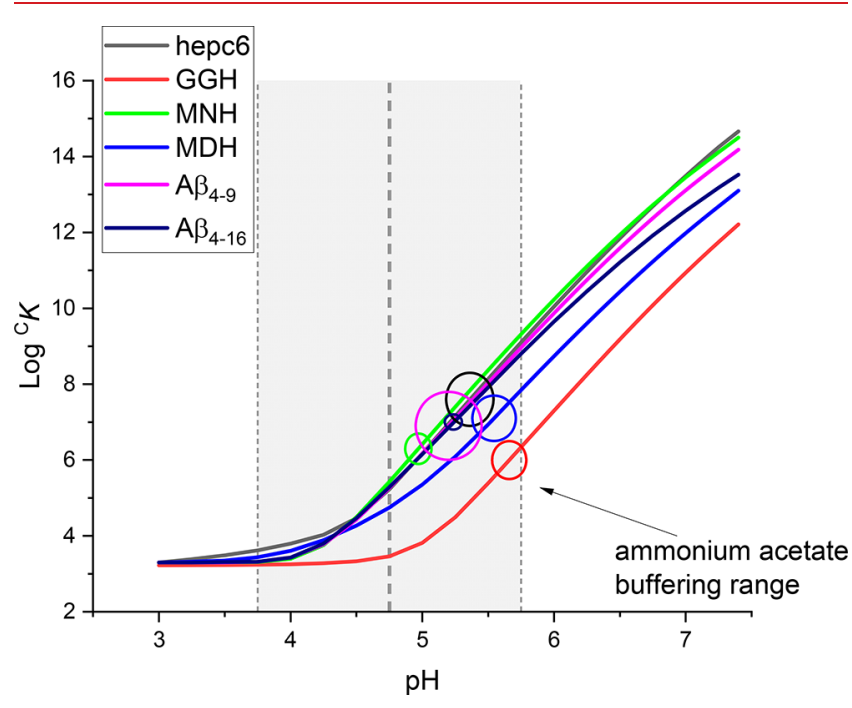

Figure 5. Prediction of $\mathrm{pH}$ values in electrospray stipulated by the literature $\log { }^{\mathrm{C}} K$ values compared with the values calculated from serial dilution ESI-MS (data from Table 1). Solid curves represent the $\mathrm{pH}$ dependence of literature $\log { }^{C} K$ values for individual peptides. Circles mark the ESI-MS-derived $\log K_{d}$ values \pm SD placed along these curves to indicate the $\mathrm{pH}$ of spray droplets expected if acidification were the sole source of the observed $K_{\mathrm{d}}$ decrease. Gray area marks the buffering zone of ammonium acetate ( $\mathrm{pH} 4.75 \pm 1)$.
$\mathrm{Cu}$ (II) affinity if droplet acidification were the only source of the observed $\log K_{\mathrm{d}}$ decrease in serial dilution experiments. Although all values are within the buffering range of acetate, their spread is rather random and covers about one $\mathrm{pH}$ unit, despite using the same experimental conditions in all respective experiments. Therefore, the acidification, while plausible, is not the only source of the studied effect and the actual $K_{\mathrm{d}}$ values cannot be simply recovered from ESI-MS data by adjusting them for a hypothetical electrospray $\mathrm{pH}$ value.

$\mathrm{Cu}$ (II) complexes are usually considered to equilibrate rapidly, but our recent study demonstrated that $\mathrm{Cu}$ (II) complexes of ATCUN peptides are formed in a stepwise manner, with the lifetime of most stable intermediate species around several hundred milliseconds. ${ }^{20}$ A typical time of electrospray formation is $\leq 10 \mathrm{~ms} .^{37,38}$ These facts prompted us to investigate whether the complexes had enough time to reach the new $\mathrm{pH}$-dependent equilibrium within the time of droplet evolution preceding the gas phase transition. To answer this question, we performed stopped-flow $\mathrm{pH}$-jump experiments. The samples containing $\mathrm{Cu}(\mathrm{II})-$ hepc6 and $\mathrm{Cu}(\mathrm{II})-$ GGH complexes in ammonium acetate at $\mathrm{pH} 7.4$ were mixed with acetic acid solutions of concentrations adjusted to reach $\mathrm{pH}$ 5,4 , or 3 after the sample mixing. The evolution of the systems was monitored using the visible absorption spectra, as shown in Figure 6 for $\mathrm{Cu}(\mathrm{II})-$ hepc6. The data for $\mathrm{Cu}(\mathrm{II})-\mathrm{GGH}$ are provided in Figure S15.

The traces at $525 \mathrm{~nm}$, corresponding to the decomposition of the 4N ATCUN complex, are presented in Figure 7 for $\mathrm{Cu}(\mathrm{II})-$ hepc6 and in Figure S16 for $\mathrm{Cu}(\mathrm{II})-\mathrm{GGH}$. The extent of dissociation of $4 \mathrm{~N}$ complexes after $10 \mathrm{~ms}$ at $\mathrm{pH} \mathrm{5,} \mathrm{4,} \mathrm{and} 3$ was measured by following the decay of their absorption peaks at 525 $\mathrm{nm}$. Due to significant noise of the absorption signal the averaged signal intensities at 0 and $10 \mathrm{~ms}$ were obtained by fitting a first order kinetic function to the absorption data. The overall fits and expanded regions of interest (0 to $30 \mathrm{~ms})$ are presented for clarity. As seen in these figures, the inertness of ATCUN complexes to acid-catalyzed dissociation in the $10 \mathrm{~ms}$ time window is significant (except for $\mathrm{Cu}(\mathrm{II})-\mathrm{GGH}$ at $\mathrm{pH} 3$ ) and must be taken into account. Table S3 presents the results of a simulation of relative abundances of apopeptides and $\mathrm{Cu}$ (II) complexes that should occur if the ESI-MS signals depended only on droplet acidification and the resulting complex dissociation after $10 \mathrm{~ms}$. This analysis indicates that the abundance of hepc6 apopeptide in ESI-MS spectra is consistent with $\mathrm{pH}$ the droplet drop to slightly above 3, while the abundance of GGH apopeptide appears to correspond with the final droplet $\mathrm{pH}$ clearly above 5. Both cannot be true for experiments performed under identical conditions. Hence, acidification and complex decay kinetics do not explain the pattern of free and complexed peptides observed in ESI-MS.

The application of the above methodology to decipher the mechanism responsible for the deviation in competition experiments is not possible because of the overlap of the $\mathrm{pH}$ and desolvation effects exerted simultaneously on the peptide and histidine complexes. The droplet acidification and/or complex unfolding processes are less significant in the mild desolvation conditions of the respective instrument, as evidenced by the control experiment. The theoretical speciation for $\mathrm{Cu}(\mathrm{A} \beta 4-16)$ at the $100 \mathrm{pM}$ concentration suggests that the $\mathrm{pH}$ drop may be actually very low or none (Figure S11). In accord, the attempt to assign a $\mathrm{pH}$ drop to competition experiments proved futile, as presented in Figure 8. Therefore, 


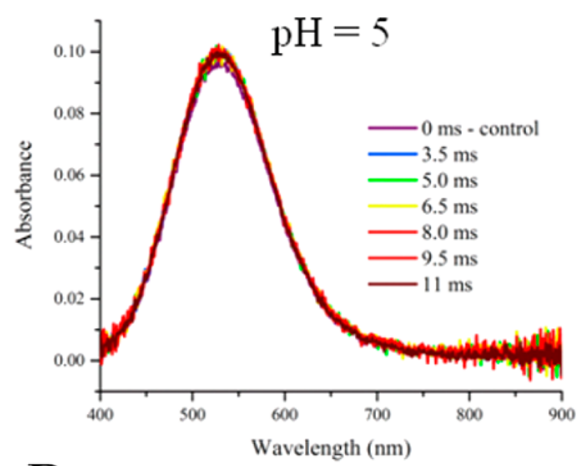

$\mathrm{B}$

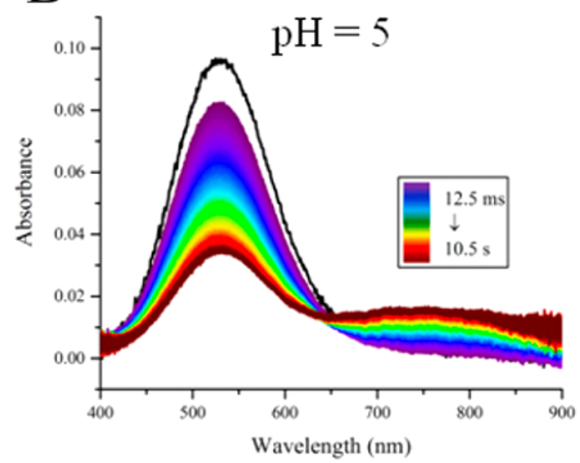

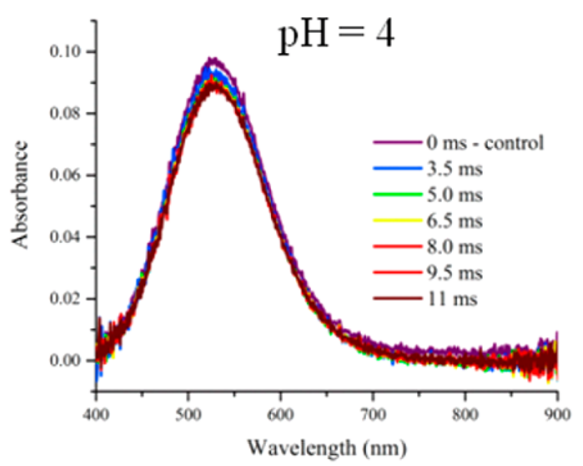
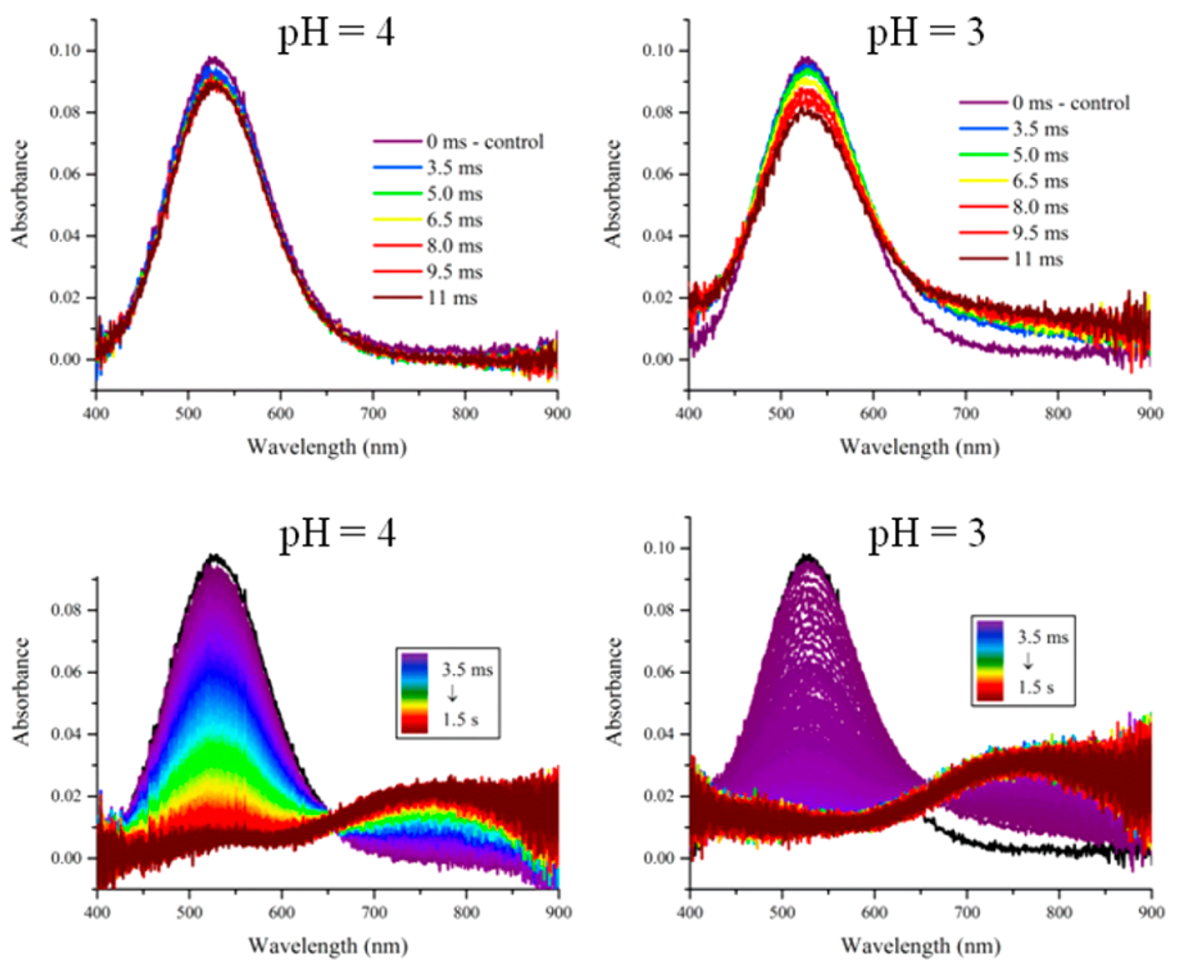

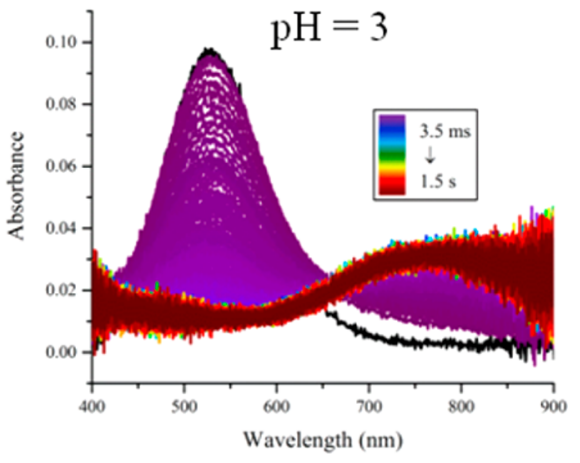

Figure 6. Stopped-flow spectra of $\mathrm{Cu}(\mathrm{II})$-hepc6 in $20 \mathrm{mM}$ ammonium acetate initially at $\mathrm{pH}$ 7.4, subjected to rapid pH decrease by mixing with concentrated acetic acid. Color-coded spectra were recorded every $1.5 \mathrm{~ms}$ with the instrument dead time of $2 \mathrm{~ms}$. (A) First $11 \mathrm{~ms}$ of the reaction and (B) all spectra recorded until equilibrium was reached. The band at $525 \mathrm{~nm}$ represents the fully formed (4N) ATCUN complex, stable at pH 7.4, and the band at $750 \mathrm{~nm}$ represents the intermediate $(2 \mathrm{~N})$ complex. $^{20}$

the systematic error embedded in these experiments is likely due to complex desolvation phenomena, as discussed below.

\section{DISCUSSION}

The experimental results presented in Figure 3 and Figures S1S6 and S12-S13 showed that the proportions of free ATCUN peptides and their complexes in ammonium acetate solutions at $\mathrm{pH}$ 7.4, obtained by ESI-MS, do not match the expectations based on ${ }^{C} K_{7.4}$ values obtained by other techniques (Tables 1 and 2). This cannot be assigned to a nonproportionate efficacy of ionization of respective species, a well-known phenomenon in ESI-MS, ${ }^{30}$ because the discrepancy is far too high.

In the case of histidine competition experiments, a disproportional ionization would shift the binding curve but should not yield a steeper transition from free to complexed peptide. Doing so would indicate that ionization efficiency difference reverses in changing concentrations of the competitor. Interestingly, at low histidine concentrations the apparent $\mathrm{Cu}$ (II) binding by the peptides is slightly enhanced beyond the expected value. This could be caused by the fact that during shrinking of the droplet, when concentrations rise, His escapes the droplets earlier. This would shift the equilibrium in favor of the peptide. No such effect is observed, however, at higher histidine concentrations.

In the case of serial dilutions, the artifactual surplus of free peptides was not alleviated even at a high $\mathrm{Cu}^{2+}$ excess (Figures S7-S9). The analysis of relative peak intensities excluded the $\mathrm{Cu}(\mathrm{II})$ reduction to $\mathrm{Cu}(\mathrm{I})$ as a significant source of this discrepancy (Figure S10). The significant amounts of apopeptides in the spectra resembled the $\mathrm{Cu}^{2+} /$ peptide equilibria under the acidic conditions (Figures 4 and S14), which appeared to correlate with the noted acidification of ammonium acetate solutions upon the electrospray droplet formation. ${ }^{52}$ Quantitative analysis demonstrated, however, that the apparent $\mathrm{pH}$ values derived from ESI-MS data are spread randomly over nearly one $\mathrm{pH}$ unit (5.0-5.7, Figure 5), effectively precluding a quantitative use of such data. Additionally, this apparent $\mathrm{pH}$ shift was less than expected for droplet acidification according to Konermann (around 4.75). ${ }^{52}$ Looking for a reason, we turned to $\mathrm{pH}$-jump kinetic experiments, guided by our recent discovery of intermediate steps in the process of ATCUN complex formation, which could overlap with the lifetime of electrospray droplets. ${ }^{20,41}$ These experiments, presented in Figures 6, 7, S15, and S16, revealed that the studied complexes are far too inert to undergo a significant decomposition within the $10 \mathrm{~ms}$ time window facing the relevant extent of acidification. Therefore, the main reason for the complex dissociation was in this case an inadequate ESI source or its parameters. Tuning of voltage, gas flow, or injection flow did not yield considerable success. However, changing the spectrometer to the one dedicated to intact noncovalent bonds yielded much more accurate results. The apparent binding constants were much closer to expected values derived from solution studies but were still significantly underestimated.

We propose that the clue for the observed effect is provided by thermodynamics of $\mathrm{Cu}$ (II) complex formation. The ITC investigation of DAHK, an ATCUN peptide model of human serum albumin, demonstrated that the $\mathrm{Cu}(\mathrm{DAHK})$ complex at neutral $\mathrm{pH}$ is stabilized solely by entropic contribution. ${ }^{50}$ At this $\mathrm{pH}$ the enthalpic contributions such as Coulombic attraction are canceled out by the cost of deprotonations of peptide nitrogens 
A
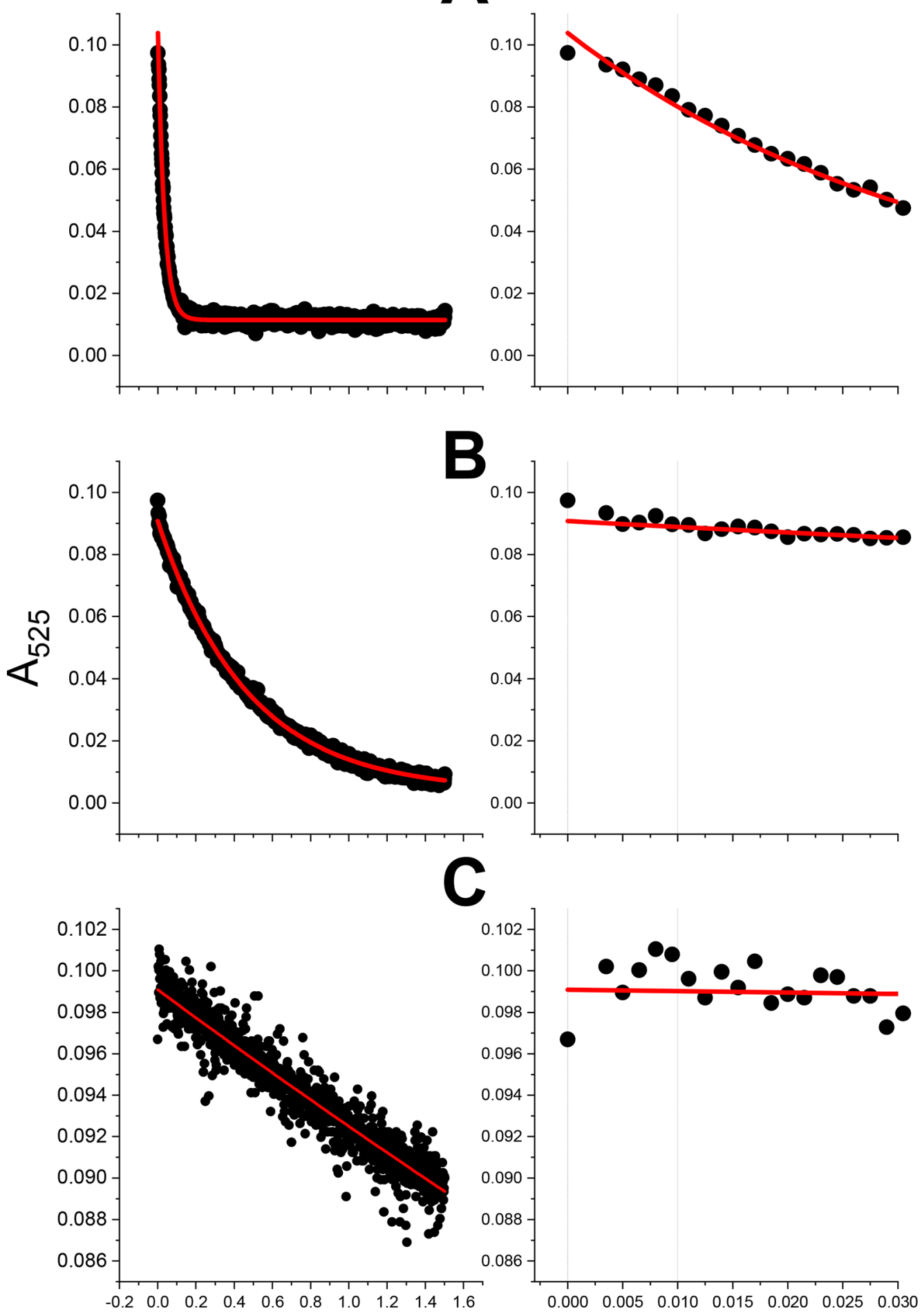

\section{time (s)}

Figure 7. Kinetic traces at $525 \mathrm{~nm}$ for pH-jump experiments on $\mathrm{Cu}$ (II)-hepc6 presented in Figure 6 for $\mathrm{pH} 3$ (A), 4 (B), and 5 (C). Left: full traces recorded over $1.5 \mathrm{~s}$ and 1 st order kinetic fits (red lines). Right: the first $30 \mathrm{~ms}$ of traces. Vertical lines mark the $0 \mathrm{~ms}$ (reaction start) and the $10 \mathrm{~ms}$ time points.

some 8 orders of magnitude below its $K_{\mathrm{a}}{ }^{70}$ The main contributor to complex stability is believed to be a release of water molecules from hydration shells of $\mathrm{Cu}$ (II) and the peptide, as well as deprotonation. Stable 4-nitrogen-Cu(II) complex leaves much less peptide and metal exposed to the solvent; thus, the entropic factor comes from the combination of folding and desolvation. A similar feature was observed for $\mathrm{Cu}$ (II) binding to metalloproteins. ${ }^{51,71}$ Therefore, in accordance with the data 

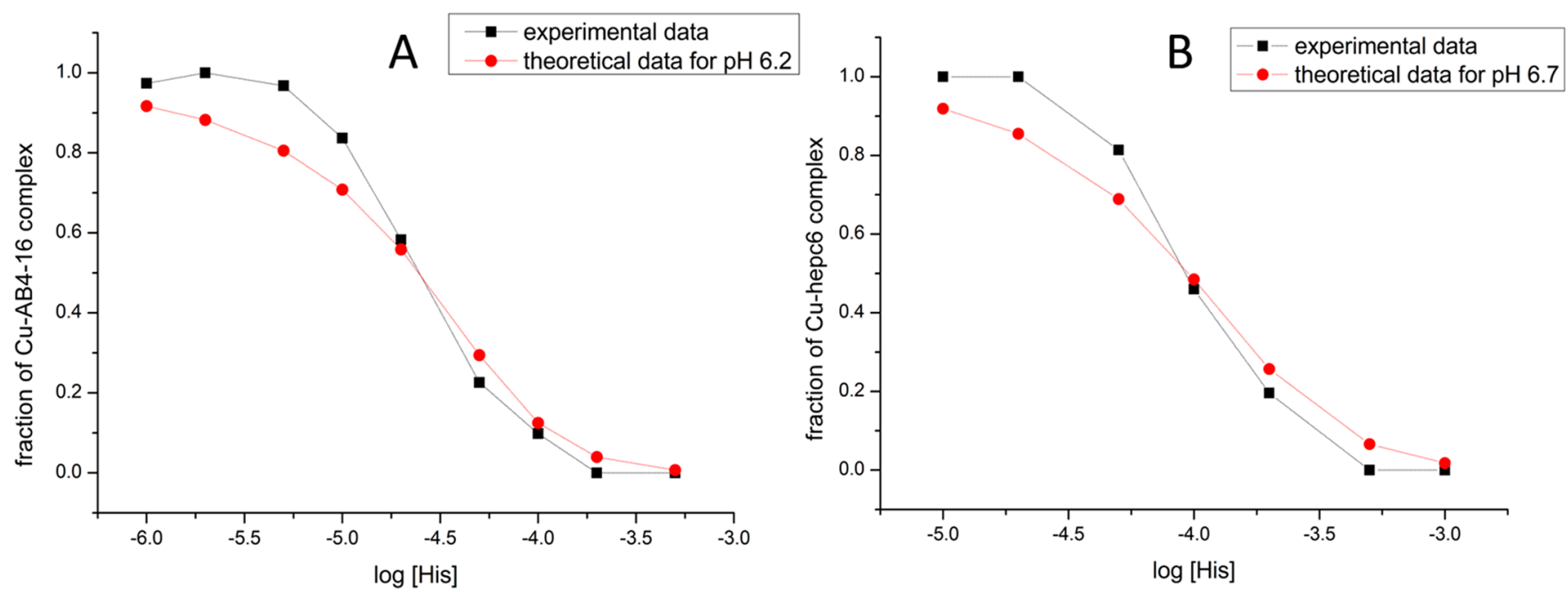

Figure 8. Experimental and theoretical binding isotherms of $\mathrm{Cu} / \mathrm{A} \beta 4-16(\mathrm{~A})$ and $\mathrm{Cu} / \mathrm{hepc6}(\mathrm{B}) 1: 1$ complexes titrated with histidine as weak competitor.

presented above, the removal of water from the second coordination sphere of a $\mathrm{Cu}(\mathrm{II})-\mathrm{ATCUN}$ complex will likely lead to the equilibrium shift and possible subsequent complex decomposition upon entry of the molecules into the gas phase. It was previously established that thermodynamic changes occur during transition to the gas phase and entropically favored forces become destabilized. ${ }^{28}$ Additionally, acid-dissociated $\mathrm{Cu}^{2+}$ ions may recombine with the peptide upon its transition to the gas phase, additionally confounding the observations. ${ }^{72}$ From this perspective, one can state that neither ESI-MS nor other mass spectrometry techniques should be applied in quantitative studies of $\mathrm{Cu}(\mathrm{II})$-peptide complexes. If such experiments are performed, the resulting binding constant will always be lower than the real one, but to an extent impossible to predict without independent data obtained by a different method. Therefore, mass spectrometry data for $\mathrm{Cu}(\mathrm{II}) /$ peptide binding constants should be regarded as "greater than $x$ ", always with an assumption that the in-solution binding constant is higher than that measured. On the other hand, enthalpic contributions are significant or decisive for the stability of other metal chelates in water, ${ }^{73,74}$ and hence, metal complex formation can be studied by MS upon maintaining the utmost scrutiny and validating the results by independent techniques whenever possible.

\section{ASSOCIATED CONTENT}

\section{(s) Supporting Information}

The Supporting Information is available free of charge at https://pubs.acs.org/doi/10.1021/jasms.1c00206.

Serial dilution data (Figures $\mathrm{S} 1-\mathrm{S} 6$ ), $\mathrm{Cu}^{2+}$ titrations (Figures S7 and S8) and derived apparent $K_{d}$ (Figure S9), isotopic distributions for detection of $\mathrm{Cu}^{2+}$ reduction (Figure $\mathrm{S} 10$ ), calculated $\mathrm{pH}$ distribution of $\mathrm{Cu}(\mathrm{II}) \mathrm{A} \beta 4-16$ (Figure S11), raw spectra for histidine competition (Figures $\mathrm{S} 12$ and S13), literature $\log \beta$ values for $\mathrm{Cu}(\mathrm{II})$ complexes of hepc6 and A $\beta 4-16$ (Tables S1 and S2), species distributions for $\mathrm{Cu}(\mathrm{II})$ complexes of $\mathrm{MNH}$ $\mathrm{NH} 2, \mathrm{~A} \beta 4-9, \mathrm{~A} \beta 4-16$, and MDH-NH2 (Figure S14), stopped-flow spectra (Figure S15), kinetic traces (Figure S16), and recalculation of apparent spray $\mathrm{pH}$ (Table S3) (PDF)

\section{AUTHOR INFORMATION}

\section{Corresponding Author}

Wojciech Bal - Institute of Biochemistry and Biophysics, Polish Academy of Sciences, 02-106 Warsaw, Poland; (1) orcid.org/ 0000-0003-3780-083X; Email: wbal@ibb.waw.pl

\section{Authors}

Dawid Płonka - Institute of Biochemistry and Biophysics, Polish Academy of Sciences, 02-106 Warsaw, Poland; (1) orcid.org/ 0000-0002-4076-9231

Radosław Kotuniak - Institute of Biochemistry and Biophysics, Polish Academy of Sciences, 02-106 Warsaw, Poland

Katarzyna Dąbrowska - Institute of Biochemistry and Biophysics, Polish Academy of Sciences, 02-106 Warsaw, Poland

Complete contact information is available at:

https://pubs.acs.org/10.1021/jasms.1c00206

\section{Notes}

The authors declare no competing financial interest.

\section{ACKNOWLEDGMENTS}

This work was supported by National Science Center (Poland) PRELUDIUM projects no. 2018/31/N/ST4/01259 (D.P) and 2018/31/N/ST5/02556 (R.K.) The equipment used was sponsored, in part, by the Centre for Preclinical Research and Technology (CePT), a project cosponsored by the European Regional Development Fund and Innovative Economy, The National Cohesion Strategy of Poland. All measurements on Q Exactive UHMR Hybrid Quadrupole-Orbitrap mass spectrometer were done in the Mass Spectrometry Laboratory of Institute of Biochemistry and Biophysics, Polish Academy of Sciences in terms of demonstration laboratory by Thermo Scientific.

\section{REFERENCES}

(1) Pickart, L.; Thaler, M. M. Growth-modulating tripeptide (glycylhistidyllysine): Association with copper and iron in plasma, and stimulation of adhesiveness and growth of hepatoma cells in culture by tripeptide-metal ion complexes. J. Cell. Physiol. 1980, 102, 129-139.

(2) Pickart, L.; Margolina, A. Regenerative and Protective Actions of the GHK-Cu Peptide in the Light of the New Gene Data. Int. J. Mol. Sci. 2018, 19, 1987. 
(3) Duntze, W.; Stötzler, D.; Bücking-Throm, E.; Kalbitzer, S. Purification and partial characterization of -factor, a mating-type specific inhibitor of cell reproduction from Saccharomyces cerevisiae. Eur. J. Biochem. 1973, 35, 357-365.

(4) Bossak, K.; Mital, M.; Poznański, J.; Bonna, A.; Drew, S.; Bal, W. Interactions of $\alpha$-Factor-1, a Yeast Pheromone, and Its Analogue with Copper(II) Ions and Low-Molecular-Weight Ligands Yield Very Stable Complexes. Inorg. Chem. 2016, 55, 7829-7831.

(5) Shahzad, R.; Jones, M. R.; Viles, J. H.; Jones, C. E. Endocytosis of the tachykinin neuropeptide, neurokinin $\mathrm{B}$, in astrocytes and its role in cellular copper uptake. J. Inorg. Biochem. 2016, 162, 319-325.

(6) Mital, M.; Wezynfeld, N. E.; Frączyk, T.; Wiloch, M. Z.; Wawrzyniak, U. E.; Bonna, A.; Tumpach, C.; Barnham, K. J.; Haigh, C. L.; Bal, W.; Drew, S. C. A Functional Role for A $\beta$ in Metal Homeostasis? N-Truncation and High-Affinity Copper Binding. Angew. Chem., Int. Ed. 2015, 54, 10460-10464.

(7) Stefaniak, E.; Bal, W. CuII Binding Properties of N-Truncated A $\beta$ Peptides: In Search of Biological Function. Inorg. Chem. 2019, 58, 13561-13577.

(8) Bal, W.; Jeżowska-Bojczuk, M.; Kasprzak, K. S. Binding of Nickel(II) and Copper(II) to the N-Terminal Sequence of Human Protamine HP2. Chem. Res. Toxicol. 1997, 10, 906-914.

(9) Bal, W.; Lukszo, J.; Kasprzak, K. S. Mediation of Oxidative DNA Damage by Nickel(II) and Copper(II) Complexes with the $\mathrm{N}$ Terminal Sequence of Human Protamine HP2. Chem. Res. Toxicol. 1997, 10, 915-921.

(10) Liang, R.; Senturker, S.; Shi, X.; Bal, W.; Dizdaroglu, M.; Kasprzak, K. S. Effects of $\mathrm{Ni}(\mathrm{II})$ and $\mathrm{Cu}(\mathrm{II})$ on DNA interaction with the N-terminal sequence of human protamine P2: Enhancement of binding and mediation of oxidative DNA strand scission and base damage. Carcinogenesis 1999, 20, 893-898.

(11) Conklin, S. E.; Bridgman, E. C.; Su, Q.; Riggs-Gelasco, P.; Haas, K. L.; Franz, K. J. Specific Histidine Residues Confer Histatin Peptides with Copper-Dependent Activity against Candida albicans. Biochemistry 2017, 56, 4244-4255.

(12) Frączyk, T. Cu(II)-Binding N-Terminal Sequences of Human Proteins. Chem. Biodiversity 2021, 18, No. e2100043.

(13) Sokolowska, M.; Krezel, A.; Dyba, M.; Szewczuk, Z.; Bal, W. Short peptides are not reliable models of thermodynamic and kinetic properties of the $\mathrm{N}$-terminal metal binding site in serum albumin. Eur. J. Biochem. 2002, 269, 1323-1331.

(14) Haas, K. L.; Putterman, A. B.; White, D. R.; Thiele, D. J.; Franz, $\mathrm{K}$. J. Model peptides provide new insights into the role of histidine residues as potential ligands in human cellular copper acquisition via Ctr1. J. Am. Chem. Soc. 2011, 133, 4427-4437.

(15) Stefaniak, E.; Płonka, D.; Drew, S. C.; Bossak-Ahmad, K.; Haas, K. L.; Pushie, M. J.; Faller, P.; Wezynfeld, N. E.; Bal, W. The N-terminal 14-mer model peptide of human $\mathrm{Ctr} 1$ can collect $\mathrm{Cu}$ (ii) from albumin. Implications for copper uptake by Ctr1. Metallomics 2018, 10, 17231727.

(16) Arena, G.; La Mendola, D.; Pappalardo, G.; Sóvágó, I.; Rizzarelli, E. Interactions of $\mathrm{Cu}^{2+}$ with prion family peptide fragments: Considerations on affinity, speciation and coordination. Coord. Chem. Rev. 2012, 256, 2202-2218.

(17) Zawisza, I.; Rózga, M.; Bal, W. Affinity of copper and zinc ions to proteins and peptides related to neurodegenerative conditions (A $\beta$, APP, $\alpha$-synuclein, PrP). Coord. Chem. Rev. 2012, 256, 2297-2307.

(18) Gonzalez, P.; Bossak, K.; Stefaniak, E.; Hureau, C.; Raibaut, L.; Bal, W.; Faller, P. N-Terminal Cu-Binding Motifs (Xxx-Zzz-His, XxxHis) and Their Derivatives: Chemistry, Biology and Medicinal Applications. Chem. - Eur. J. 2018, 24, 8029-8041.

(19) Nagaj, J.; Stokowa-Sołtys, K.; Zawisza, I.; Jeżowska-Bojczuk, M.; Bonna, A.; Bal, W. Selective control of $\mathrm{Cu}$ (II) complex stability in histidine peptides by $\beta$-alanine. J. Inorg. Biochem. 2013, 119, 85-89.

(20) Kotuniak, R.; Strampraad, M. J. F.; Bossak-Ahmad, K.; Wawrzyniak, U. E.; Ufnalska, I.; Hagedoorn, P.-L.; Bal, W. Key Intermediate Species Reveal the Copper(II)-Exchange Pathway in Biorelevant ATCUN/NTS Complexes. Angew. Chem., Int. Ed. 2020, 59, 11234-11239.
(21) Bossak-Ahmad, K.; Frączyk, T.; Bal, W.; Drew, S. C. The Subpicomolar $\mathrm{Cu}^{2+}$ Dissociation Constant of Human Serum Albumin. ChemBioChem 2020, 21, 331-334.

(22) Magrì, A.; Tabbì, G.; Giuffrida, A.; Pappalardo, G.; Satriano, C.; Naletova, I.; Nicoletti, V. G.; Attanasio, F. Influence of the N-terminus acetylation of Semax, a synthetic analog of ACTH(4-10), on copper(II) and zinc(II) coordination and biological properties. J. Inorg. Biochem. 2016, 164, 59-69.

(23) Gavriilidou, A. F. M.; Gülbakan, B.; Zenobi, R. Influence of Ammonium Acetate Concentration on Receptor-Ligand Binding Affinities Measured by Native Nano ESI-MS: A Systematic Study. Anal. Chem. 2015, 87, 10378-10384.

(24) Erba, E. B.; Zenobi, R. Mass spectrometric studies of dissociation constants of noncovalent complexes. Annu. Rep. Prog. Chem., Sect. C: Phys. Chem. 2011, 107, 199.

(25) Daniel, J. M.; McCombie, G.; Wendt, S.; Zenobi, R. Mass spectrometric determination of association constants of adenylate kinase with two noncovalent inhibitors. J. Am. Soc. Mass Spectrom. 2003, 14, 442-448.

(26) Peschke, M.; Verkerk, U. H.; Kebarle, P. Features of the ESI mechanism that affect the observation of multiply charged noncovalent protein complexes and the determination of the association constant by the titration method. J. Am. Soc. Mass Spectrom. 2004, 15, 1424-1434.

(27) Zhang, S.; van Pelt, C. K.; Wilson, D. B. Quantitative determination of noncovalent binding interactions using automated nanoelectrospray mass spectrometry. Anal. Chem. 2003, 75, 30103018.

(28) Carlton, D. D., Jr; Schug, K. A. A review on the interrogation of peptide-metal interactions using electrospray ionization-mass spectrometry. Anal. Chim. Acta 2011, 686, 1-39.

(29) Jecklin, M. C.; Touboul, D.; Bovet, C.; Wortmann, A.; Zenobi, R. Which electrospray-based ionization method best reflects proteinligand interactions found in solution? a comparison of ESI, nanoESI, and ESSI for the determination of dissociation constants with mass spectrometry. J. Am. Soc. Mass Spectrom. 2008, 19, 332-343.

(30) Kitova, E. N.; El-Hawiet, A.; Schnier, P. D.; Klassen, J. S. Reliable Determinations of Protein-Ligand Interactions by Direct ESI-MS Measurements. Are We There Yet? J. Am. Soc. Mass Spectrom. 2012, 23, 431-441.

(31) Smirnova, J.; Zhukova, L.; Witkiewicz-Kucharczyk, A.; Kopera, E.; Olędzki, J.; Wysłouch-Cieszyńska, A.; Palumaa, P.; Hartwig, A.; Bal, W. Quantitative electrospray ionization mass spectrometry of zinc finger oxidation: The reaction of XPA zinc finger with $\mathrm{H} 2 \mathrm{O} 2$. Anal. Biochem. 2007, 369, 226-231.

(32) Shoshan, M. S.; Dekel, N.; Goch, W.; Shalev, D. E.; Danieli, T.; Lebendiker, M.; Bal, W.; Tshuva, E. Y. Unbound position II in MXCXXC metallochaperone model peptides impacts metal binding mode and reactivity: Distinct similarities to whole proteins. J. Inorg. Biochem. 2016, 159, 29-36.

(33) Piątek, K.; Schwerdtle, T.; Hartwig, A.; Bal, W. Monomethylarsonous Acid Destroys a Tetrathiolate Zinc Finger Much More Efficiently than Inorganic Arsenite: Mechanistic Considerations and Consequences for DNA Repair Inhibition. Chem. Res. Toxicol. 2008, 21, 600-606.

(34) Whittal, R. M.; Ball, H. L.; Cohen, F. E.; Burlingame, A. L.; Prusiner, S. B.; Baldwin, M. A. Copper binding to octarepeat peptides of the prion protein monitored by mass spectrometry. Protein Sci. 2000, 9, 332-343.

(35) Di Marco, V. B.; Bombi, G. G. Electrospray mass spectrometry (ESI-MS) in the study of metal-ligand solution equilibria. Mass Spectrom. Rev. 2006, 25, 347-379.

(36) Wyttenbach, T.; Liu, D.; Bowers, M. T. Interactions of the hormone oxytocin with divalent metal ions. J. Am. Chem. Soc. 2008, 130, $5993-6000$

(37) Ikonomou, M. G.; Blades, A. T.; Kebarle, P. Investigations of the Electrospray Interface for Liquid Chromatography/Mass Spectrometry. Anal. Chem. 1990, 62, 957-967.

(38) Wortmann, A.; Kistler-Momotova, A.; Zenobi, R.; Heine, M. C.; Wilhelm, O.; Pratsinis, S. E. Shrinking droplets in electrospray 
ionization and their influence on chemical equilibria. J. Am. Soc. Mass Spectrom. 2007, 18, 385-393.

(39) Kebarle, P.; Tang, L. From ions in solution to ions in the gas phase-the mechanism of electrospray mass spectrometry. Anal. Chem. 1993, 65, 972A-986A.

(40) Wilkins, R. G. Kinetics and mechanism of reactions of transition metal complexes, 2nd ed.; VCH: Weinheim, online resource, 2003.

(41) Teng, X.; Stefaniak, E.; Girvan, P.; Kotuniak, R.; Płonka, D.; Bal, W.; Ying, L. Hierarchical binding of copperII to N-truncated A $\beta 4-16$ peptide. Metallomics 2020, 12, 470-473.

(42) Matsumoto, A.; Fukumoto, T.; Adachi, H.; Watarai, H. Electrospray ionization mass spectrometry of metal complexes. Gas phase formation of a binuclear copper(II)-5-Br-PADAP complex. Anal. Chim. Acta 1999, 390, 193-199.

(43) Dill, K. A. Dominant forces in protein folding. Biochemistry 1990, 29, 7133-7155.

(44) Doonan, S. Peptides and proteins; Royal Society of Chemistry: Cambridge, 2002.

(45) Zhou, S.; Cook, K. D. Protonation in electrospray mass spectrometry: Wrong-way-round or right-way-round? J. Am. Soc. Mass Spectrom. 2000, 11, 961-966.

(46) Wu, Q.; Gao, J.; Joseph-McCarthy, D.; Sigal, G. B.; Bruce, J. E.; Whitesides, G. M.; Smith, R. D. Carbonic Anhydrase-Inhibitor Binding: From Solution to the Gas Phase. J. Am. Chem. Soc. 1997, 119, 11571158.

(47) Wales, T. E.; Engen, J. R. Partial unfolding of diverse SH3 domains on a wide timescale. J. Mol. Biol. 2006, 357, 1592-1604.

(48) Orte, A.; Craggs, T. D.; White, S. S.; Jackson, S. E.; Klenerman, D. Evidence of an intermediate and parallel pathways in protein unfolding from single-molecule fluorescence. J. Am. Chem. Soc. 2008, 130, 78987907.

(49) Kubelka, J.; Eaton, W. A.; Hofrichter, J. Experimental Tests of Villin Subdomain Folding Simulations. J. Mol. Biol. 2003, 329, 625630.

(50) Trapaidze, A.; Hureau, C.; Bal, W.; Winterhalter, M.; Faller, P. Thermodynamic study of $\mathrm{Cu} 2+$ binding to the DAHK and GHK peptides by isothermal titration calorimetry (ITC) with the weaker competitor glycine. JBIC, J. Biol. Inorg. Chem. 2012, 17, 37-47.

(51) North, M. L.; Wilcox, D. E. Shift from Entropic Cu2+ Binding to Enthalpic $\mathrm{Cu}+$ Binding Determines the Reduction Thermodynamics of Blue Copper Proteins. J. Am. Chem. Soc. 2019, 141, 14329-14339.

(52) Konermann, L. Addressing a Common Misconception: Ammonium Acetate as Neutral pH "Buffer" for Native Electrospray Mass Spectrometry. J. Am. Soc. Mass Spectrom. 2017, 28, 1827-1835.

(53) Raamat, E.; Kaupmees, K.; Ovsjannikov, G.; Trummal, A.; Kütt, A.; Saame, J.; Koppel, I.; Kaljurand, I.; Lipping, L.; Rodima, T.; Pihl, V.; Koppel, I. A.; Leito, I. Acidities of strong neutral Brønsted acids in different media. J. Phys. Org. Chem. 2013, 26, 162-170.

(54) Wang, H.; Agnes, G. R. Kinetically labile equilibrium shifts induced by the electrospray process. Anal. Chem. 1999, 71, 4166-4172.

(55) McDonald, L. W.; Campbell, J. A.; Clark, S. B. Failure of ESI spectra to represent metal-complex solution composition: A study of lanthanide-carboxylate complexes. Anal. Chem. 2014, 86, 1023-1029.

(56) Zhang, M.; Gumerov, D. R.; Kaltashov, I. A.; Mason, A. B. Indirect detection of protein-metal binding: Interaction of serum transferrin with In3+ and Bi3+. J. Am. Soc. Mass Spectrom. 2004, 15, $1658-1664$.

(57) Gatlin, C. L.; Turecek, F.; Vaisar, T. Determination of soluble Cu (I) and $\mathrm{Cu}$ (II) species in jet fuel by electrospray ionization mass spectrometry. Anal. Chem. 1994, 66, 3950-3958.

(58) Lavanant, H.; Hoppilliard, Y. Formation and fragmentation of $\alpha$ amino acids complexed by $\mathrm{Cu}+$. J. Mass Spectrom. 1997, 32, 10371049.

(59) Lavanant, H.; Virelizier, H.; Hoppilliard, Y. Reduction of copper (II) complexes by electron capture in an electrospray ionization source. J. Am. Soc. Mass Spectrom. 1998, 9, 1217-1221.

(60) Tsybizova, A.; Roithová, J. Copper-catalyzed reactions: Research in the gas phase. Mass Spectrom. Rev. 2016, 35, 85-110.
(61) Di Marco, V. B.; Bombi, G. G.; Zambon, S.; Traldi, P. Metalligand solution equilibria studied by electrospray ionization mass spectrometry: Effect of instrumental parameters. J. Mass Spectrom. 2009, 44, 120-127.

(62) Kotuniak, R.; Frączyk, T.; Skrobecki, P.; Płonka, D.; Bal, W. GlyHis-Thr-Asp-Amide, an Insulin-Activating Peptide from the Human Pancreas Is a Strong $\mathrm{Cu}$ (II) but a Weak $\mathrm{Zn}$ (II) Chelator. Inorg. Chem. 2018, 57, 15507-15516.

(63) Płonka, D.; Bal, W. The N-terminus of hepcidin is a strong and potentially biologically relevant $\mathrm{Cu}$ (II) chelator. Inorg. Chim. Acta 2018, 472, 76-81.

(64) Bossak, K.; Drew, S. C.; Stefaniak, E.; Płonka, D.; Bonna, A.; Bal, $\mathrm{W}$. The $\mathrm{Cu}(\mathrm{II})$ affinity of the $\mathrm{N}$-terminus of human copper transporter CTR1: Comparison of human and mouse sequences. J. Inorg. Biochem. 2018, 182, 230-237.

(65) Bossak-Ahmad, K.; Mital, M.; Płonka, D.; Drew, S. C.; Bal, W. Oligopeptides Generated by Neprilysin Degradation of $\beta$-Amyloid Have the Highest $\mathrm{Cu}$ (II) Affinity in the Whole $\mathrm{A} \beta$ Family. Inorg. Chem. 2019, 58, 932-943.

(66) Young, T. R.; Xiao, Z. Principles and practice of determining metal-protein affinities. Biochem. J. 2021, 478, 1085-1116.

(67) Sokołowska, M.; Bal, W. Cu(II) complexation by "noncoordinating” N-2-hydroxyethylpiperazine- $\mathrm{N}^{\prime}$-2-ethanesulfonic acid (HEPES buffer). J. Inorg. Biochem. 2005, 99, 1653-1660.

(68) Krężel, A.; Wójcik, J.; Maciejczyk, M.; Bal, W. May GSH and LHis contribute to intracellular binding of zinc? Thermodynamic and solution structural study of a ternary complex. Chem. Commun. 2003, 704-705.

(69) Jeżowska-Bojczuk, M.; Kaczmarek, P.; Bal, W.; Kasprzak, K. S. Coordination mode and oxidation susceptibility of nickel(II) complexes with 2'-deoxyguanosine 5 '-monophosphate and L-histidine. J. Inorg. Biochem. 2004, 98, 1770-1777.

(70) Sigel, H.; Martin, R. B. Coordinating properties of the amide bond. Stability and structure of metal ion complexes of peptides and related ligands. Chem. Rev. 1982, 82, 385-426.

(71) Wilcox, D. E. Isothermal titration calorimetry of metal ions binding to proteins: An overview of recent studies. Inorg. Chim. Acta 2008, 361, 857-867.

(72) Kostyukevich, Y.; Kononikhin, A.; Popov, I.; Indeykina, M.; Kozin, S. A.; Makarov, A. A.; Nikolaev, E. Supermetallization of peptides and proteins during electrospray ionization. J. Mass Spectrom. 2015, 50, 1079-1087.

(73) Beech, G. Some recent studies in the thermodynamics of metal complex formation. Q. Rev., Chem. Soc. 1969, 23, 410.

(74) Vallet, V.; Wahlgren, U.; Grenthe, I. Chelate effect and thermodynamics of metal complex formation in solution: A quantum chemical study. J. Am. Chem. Soc. 2003, 125, 14941-14950. 